\title{
A Confirmation of Indonesian EFL Students' Achievement and Views in Translation through Mobile-Assisted Language Learning
}

\author{
Danti Pudjiati \\ dantipudjiati@stkipkusumanegara.ac.id \\ STKIP Kusuma Negara, Indonesia \\ Sianna \\ sianna@umpar.ac.id \\ Universitas Muhammadiyah Parepare, Indonesia \\ Tira Nur Fitria (Corresponding Author) \\ tiranurfitria@gmail.com \\ Institut Teknologi Bisnis AAS, Indonesia
}

\begin{abstract}
MALL in translation is increasingly prevalent among Indonesian EFL students due to ICT development and practical usage in teaching and learning. In addressing this issue, this research assessed the students' success and understanding by using MALL to translate a coronavirus text. There are four issues to consider: 1) Is MALL helpful in improving students' translation abilities? 2) How do students see MALL translate a text from English to Indonesian? 3) How does MALL help them cope with language competency when translating a text from English to Indonesian? 4) What challenges do students have while translating a text from English to Indonesian using MALL? This research was performed using qualitative and quantitative methods (Mix Methods). The research possessed 85 undergraduate students from East Jakarta and South Sulawesi as the respondents. Data was amassed through an online survey, a semi-structured interview, and document analysis. After attending the MALL online learning session, a paired-sample t-test indicated a significantly different score across the students. According to the survey, interview, and document analysis findings, they had a positive attitude about MALL for translation. They had acquired powerful support in terms of word order, word choice, and sentence structure. Nonetheless, most of them agreed that the technical issue and the lack of assistance were the most significant obstacles to successfully operating the MALL for translation.
\end{abstract}

Keywords: Mobile Assisted Language Learning (MALL); Language Translator (LT); Students' achivement and views.

\section{A. INTRODUCTION}

The technology for mobile devices is continuously developing, and widespread ownership seems to affect language training and learning in other situations. In earlier CALL applications, most learning environments were based on fixed PCs. The 
traditional CALL developed from a computer-based learning and training design that is widely known outside language teaching. We need a computer plus speakers and a CDROM for the audio software to run this program. It has now been adapted for mobile devices, enabling language learning wherever and whenever convenient. In the future, both desktop and mobile applications will be available concurrently. Multipurpose mobile devices, such as those used in the MALL app examples above, may assist language students in developing a more holistic understanding of the language (Yang, 2013). The use of mobile devices to aid language learning is known as MALL (Wu et al, 2018). When mobile devices were introduced, it became evident that MALL might play an essential role in contextualized learning (Alona \& Hagit, 2019).

CALL and MALL have developed in the realm of language teaching (Orkun, 2020). MALL has become a substantial CALL component in a brief period (Sanz et al, 2015). According to Fansury et al. (2021), based on their differences, MALL is more likely to do business using mobile devices or smartphones, while CALL is more likely to conduct business using computers, such as desktop or laptop computers. The MALL in question is a Language Translator (hereafter, LT). Without an internet connection, the extreme LT might be engaged. For added convenience, students must download the app from the Android Market and choose Indonesian as the target language for translation, since English is automatic featured in the program's source language list as a requirement to utilize it.

Additionally, LT supports over 100 languages worldwide. As a market leader, it includes elements from a written text and auditory and visual sources, resulting in a more comprehensive experience. For example, the translation may result in a text with aspects of the original language's speech. To put it another way, voice translation, like other translation services with limited capabilities, is also available to the public.

A large body of research on MALL as a practical application, particularly for improving English proficiency or ability, has already been conducted; this is a good starting point. To show this, Amalia (2020) used an experimental study to demonstrate the usefulness of using MALL adapted by Kepham from Android to teach pronunciation in a secondary school in Banten. Three researches, for example, looked at students' perceptions of MALL to increase English learning, similar to the findings mentioned above. Darsih \& Asikin (2020) reported that over 100 university students in Jawa Barat 
expressed their opinions on MALL usage and deemed it valuable, beneficial to their learning, and simple to use. In addition, Ekinci \& Ekinci (2017) studied MALL surveyed university students in Turkey to determine how they felt about the company. Their research observed that it helps pupils feel more motivated while learning a language and makes learning more efficient, especially when it comes to vocabulary acquisition. Besides, Islam \& Hasan (2020) researched higher education students to determine the influence of MALL on English language listening abilities. An electronic search of the York University library database, Google Scholar, or peer-reviewed online journals yielded the articles in question. It was established that they were helpful in teaching and developing ESL/EFL listening skills. Further research shows the powerful of MALL in English teaching. The use of gadgets in the learning process, especially language learning, deserves to be elaborated with other learning methods or media. In the era of technological sophistication, the presence of smartphones requires teachers to be more creative in using various applications and content attached to this gadget. Current students cannot be separated from smartphones. The result of this study shows how smartphones are tools that enable better language competency in students, but of course, with proper and wise supervision and use (Habibie, 2021).

According to Taj et al. (2016), MALL has emerged as a potentially valuable tool in the complex process of language acquisition. It is now being tested. The purpose of this meta-analysis was to gather all the knowledge gained so far in the field of multi-level learning. The results demonstrate the effectiveness of the MALL platform in the context of EFL education. According to AbuSa'aleek (2014), the study of the effect of mobile devices on English language abilities should be carried out as soon as possible to maximize the advantages of mobile devices for English language learning and teaching. As a result of the essential characteristics of mobile technology, including mobility, social interaction, context-sensitivity, connection, uniqueness, and immediacy, mobile technology has played a significant role in the learning of new languages. Considering prior study and, more particular, those researchers looked at the usefulness of MALL in enhancing English learning and students' perceptions of it. In other words, this might imply that academics focused on MALL for translation in the area of EFL learners and their perceptions of it are on the right track. To address these weaknesses of previous research, in line with the usage of MALL, this research was undertaken which focused 
on the concentration of translation text from English to Indonesian utilizing MALL by English education students, as well as the students' opinions on MALL, which many researchers do not yet explore.

Translation practice experience in translating an English text using a mobile device, in this instance for pre-service teachers, is a significant event since practically everyone has had prior experience with machine translation (Fitria, 2021b). This form of translation is available for free on the internet, is simple to use, and produces accurate results in a matter of seconds (Fitria, 2021a). As a result, such information may be regarded new to several students. Therefore, the urgency to conduct a research of MALL for translation is the MALL development may take into account the students' perceptions of the mobile's performance as a valuable input for improving the function, particularly for the benefit of EFL learners in translation tasks.

We researched the use of MALL to translate text from English to Indonesian and the students' views of the application based on the above. The text's argument for translation for this research was then related to the new criterion about COVID-19's influence. In April 2021, the researchers grabbed articles from the Guardian website with one purpose in mind: to acquaint students with authentic translation training material. This study aimed to explore what students (pre-service teachers) thought about utilizing MALL to improve their capacity to translate a text from English to Indonesian and evaluate the results of the text translation. In a nutshell, four research areas are being investigated to solve this issue: The following questions were addressed: 1) Is using MALL to improve students' translating abilities effective?, 2) How do students perceive MALL in terms of assisting them in translating a text from English to Indonesian?, 3) How does MALL help them cope with language competency when translating a text from English to Indonesian?, and 4) What challenges do students face when using MALL to translate a text from English to Indonesian?.

\section{B. RESEARCH METHOD}

\section{Research Design}

The researchers employed a one-group pretest-posttest design in conjunction with a pre-experimental design to conduct their study. Due to the lack of group control of another variable, pre-experimental design is pathetic. It is only employed seldom in 
educational research for substantive and academic reasons (Rukminingsih et al., 2020). Consequently, we chose this design for engaging and assessing students' translation text results in a careful manner that necessitates equal expertise capability and time management in the coordination of study participants. As a result, tests were used as instruments in this study to address the first research question.

However, since our findings are meant to determine if the value of MALL for translation as a learning aid for students warrants future examination, this research was classified as an exploratory study (Abbuhl, 2015). An online survey, a semi-structured interview, and document analysis were utilized to gather students' perspectives to answer the second, third, and fourth research questions. Using more than one technique or resource for triangulation (data gathering), such as surveys and interviews, may assist researchers in getting feedback from a more significant number of people, which raises the credibility of the study results (Creswell, 2014).

\section{Respondents and Settings of Research}

85 female and male students from East Jakarta and South Sulawesi participated in the event, with 49 from East Jakarta and 36 from South Sulawesi. Their ages ranged between 21 and 24 years, and all were enrolled in English education programs. We employed an information-oriented sample to choose the participant. We concentrated on the academic context, namely on students who had previously finished the semester six translation course and their readiness to engage in our study voluntarily. Among the subject's primary objectives is to educate students on translating a variety of literature from English to Indonesian. The course's working language is a combination of English and Indonesian.

This study was performed in a diverse context. Two Indonesian higher education institutions were the College of Teacher Training and Education (STKIP) Kusuma Negara in East Jakarta and the University of Muhammadiyah Pare-Pare in South

Sulawesi. Another factor is that such institutes are in charge of English language education. Given these realities, these study locations are appropriate for assisting researchers in determining their research questions and gathering data.

\section{Data Collecting Technique}

The researchers devised two methods for gathering data. Quantitative data was the first kind. We divided the data collection into three parts of online mode. The 
participants were given the task of translating an article on Coronavirus published on the Guardian website in April 2021. The article was then recomposed into 15 sentences with three purposes in mind: (1) to make it easier for participants to translate the material, (2) to make it easier for researchers to assess the translation result, and (3) to aid researchers in identifying simple, compound, and complicated phrases. The pretest was represented by 15 questions, which may be viewed in their entirety in the description below. The pretest stipulated that they translate the material independently at the start of May 2021. 1) They could check up the dictionary, according to the instructions. 2) They may seek advice from other people. 3) It was forbidden for them to employ machine translation.

The participants in the second phase received therapy through an online learning session in mid-May 2021. This session's content was recorded as a video that may be seen on the VOA channel, and the topic covered: a. An introduction to installation on the LT application. After the online learning session, the participants are comfortable and fully understand how to use LT for translation in the final phase. They had to translate the exact 15 phrases in the pretest, but the instructions were modified; they did it with LT aid and finished it in late May. As a result, all participants could successfully install this program on their mobile phones. The questions for the posttest were labeled as such.

Online surveys, closed-ended questionnaires, semi-structured interviews, and document analysis were used to acquire qualitative data. Students were requested to submit online questionnaires expressing their opinions of the LT translation tool and the issues they faced. Google Forms was used to create the survey. All participants checked the boxes next to the options they preferred in response to all of the questionnaire questions. Semi-structured interviews with ten students and interview questions were also used to elicit students' comments on the LT application. They agreed to share their ideas on their experience with LT and to reflect on what they believed had helped them improve their translating abilities during the online interview. They also discussed the challenges they had when translating the content using LT. The document analysis of posttest findings in terms of the language competence they enhanced was also looked at. To summarize, the following data gathering techniques were used to answer study questions. 


\section{Data Analysis Technique}

The researchers used a mix of quantitative and qualitative methodologies to analyze the study data. It was determined whether or not the students' translations were correct using a Nababan accuracy-rating instrument, which ranged from one to four points on a one-to-four scale. The scale measured how well they translated the material from the source text into the target text. Translation scores from the pretest and posttest were included in the quantitative data. We received 85 translations from all participants at the beginning of June. However, we examined their 46 translations at random. Initially, Nababan (2003) requested that their pretest and posttest translations be scaled, as seen in figure 1. Nonetheless, Nababan (2003) advice, which is translated into a scale in the company of its definition, is used as a reference for this study since it is simple and easy to implement. In a nutshell, this TQM may be found in the table below:

Table 1.

\section{Translation Assessment}

\begin{tabular}{ll}
\hline Scale & \multicolumn{1}{c}{ Definition } \\
\hline 1 & $\begin{array}{l}\text { There is an exact translation between the content of the source language and the } \\
\text { content of the target phrase. The assessor can comprehend the translated } \\
\text { statement, thus there is no need to rewrite it. }\end{array}$ \\
\hline 2 & $\begin{array}{l}\text { The target audience receives the material of the source sentence clearly and } \\
\text { understandably. Although rewriting and some word order tweaks are necessary, } \\
\text { the evaluator can grasp the translated statement without additional explanation. }\end{array}$ \\
\hline 3. & $\begin{array}{l}\text { The target sentence does not correctly represent the substance of the source } \\
\text { sentence. There are various challenges to be worked out with the selection of } \\
\text { lexical elements as well as the linkages between phrase, clause, and sentence } \\
\text { components. }\end{array}$ \\
\hline 4. & $\begin{array}{l}\text { The source sentence is not translated at all into the target phrase, for example, it } \\
\text { is omitted or eliminated. }\end{array}$ \\
\hline
\end{tabular}

The scale of the translation result ranges from 60 to 15, with 60 being the enormous scale and 15 being the lowest scale. The translation scale was then transformed to a raw score, then turned to a grade. A paired-sample t-test, also known as a repeated-measures t-test or a dependent t-test, was used to compare participants' pretest and posttest grades (Roever \& Phakiti, 2017).

Although every effort was made, the quantitative data, comprised of numbers, was analyzed by dividing students' replies into positive and negative categories based on the number of percentages they got. The following criteria were used to characterize their responses: Each "yes" answer was classified as a positive response. Each "no" response was classified as a negative response in a series of survey questions. Participants have 
the option of selecting several options. Following that, the responses were divided into four groups: self-regulation (SR), pedagogical contributions (PC), time efficiency (TE), and learning performance (LP).

A thematic analysis was used for the data analysis of the qualitative data. The interviews were first transcribed in a semi-structured format. After then, the data was examined for meaning units (or constructions) (Bryman, 2015). The constructs in this instance relate to the many subjects or themes based on the results (e.g., language competency, difficulties utilizing MALL). On the other hand, the themes were derived from both the interview and questionnaire data. The study paper's constructions were reported in primary topics based on the research questions. In summary, data description, presentation, and verification were used to examine qualitative data, including student answers, interviews, and document analysis.

\section{FINDINGS AND DISCUSSION}

\section{Findings}

According to the stated research goals, the outcomes of this study examined student accomplishment first, followed by students' impressions of using MALL for translation and their judgments of the hindrances associated with MALL use. To address the first study question, we examined students' pretest and posttest results after they participated in online learning and the use of LT. The paired samples T-test was used to investigate the statistical significance of the pretest and posttest scores. The results revealed a statistically significant difference between these two tests $(\mathrm{t}(46)=12.8$ and p.001), with a modest effect size (Cohen's $d=1.89$ ). As a result, it's possible to deduce that students' translation skills might increase after utilizing MALL.

Table 2

Paired Samples T-Test

Paired Samples T-Test

\begin{tabular}{|c|c|c|c|c|c|c|c|c|c|c|c|}
\hline & & & & & & & & & $\begin{array}{l}95 \% \\
\text { Confidence } \\
\text { Interval }\end{array}$ & & \\
\hline & & & statistic & df & $\mathrm{p}$ & $\begin{array}{l}\text { Mean } \\
\text { differe } \\
\text { nce }\end{array}$ & $\begin{array}{l}\text { SE } \\
\text { differe } \\
\text { nce }\end{array}$ & Lower & Upper & & $\begin{array}{l}\text { Effect } \\
\text { Size }\end{array}$ \\
\hline $\begin{array}{l}\text { Post } \\
\text { test }\end{array}$ & $\begin{array}{l}\text { Pre } \\
\text { test }\end{array}$ & $\begin{array}{l}\text { Stude } \\
\text { nt's t }\end{array}$ & $\begin{array}{l}12 . \\
8\end{array}$ & $\begin{array}{l}45 . \\
0\end{array}$ & $\begin{array}{l}<.00 \\
1\end{array}$ & 11.3 & 0.877 & 9.79 & Inf & $\begin{array}{l}\text { Coh } \\
\text { en's } \\
\text { d }\end{array}$ & 1.89 \\
\hline
\end{tabular}


As evidenced by the change in mean scores shown in the table below, the students appeared to have done better on their post-test. The mean posttest score was 86.4, whereas the pretest score was 75.1. Although the posttest's mean score was higher, the standard deviation revealed that the posttest results were less homogeneous Students seemed to have more significant impacts in their posttest based on descriptive statistics.

Table 3

Participants' Performance on the Posttest and Pretest

\begin{tabular}{llllll} 
& N & Mean & Median & SD & SE \\
\hline Posttest & 46 & 86.4 & 87.0 & 3.49 & 0.514 \\
Pretest & 46 & 75.1 & 77.0 & 6.28 & 0.926 \\
\hline
\end{tabular}

According to an online poll conducted using a Google form, 85 students responded to MALL's request for translation. The following is a detailed discussion of what we have discussed.

Students' opinions of MALL as a tool for assisting them in translating a text from

\section{English to Indonesian}

Students responded to five categorizations PC stands for pedagogical contribution, SR for self-regulation, LP for learning performance, TE for time efficiency, and PT for a professional translator (PT). The deductions from the interview supported up those five categorizations' responses. Figure 4 depicts the students' replies, revealing that most of the students gave good responses to the MALL for assisting them in translating a text from English to Indonesian.

The students mostly gave positive reactions to all of the categorizations. They expressed favorably with the maximum proportion of 95 percent for pedagogical contribution, i.e., it was easy to accomplish the translation task using LT, and they had sufficient time to practice independently. They said in an interview that LT was an excellent and helpful tool for a multitude of reasons, including its ability to translate both online and offline. It may, however, translate from word to phrase and listen to the pronunciation of the word. 
The second-highest proportion, Self-regulation, scored 89.6 percent, and students stated that using LT helped them perform effectively on translation-related activities. As a result of the interview, it was discovered that LT was convenient since it could be used offline. Furthermore, the word arrangement in LT was more structured than that of Google translate. The third percentage, which went to learning performance, was 87 percent. The students believed that their comprehension of the translation work had improved. The dialogue revealed that they were comfortable using LT and using its advantages. For time efficiency, the fourth percentage was 80.5 percent. After the online class, the students said they had a lot of time discussing the course topic. They affirmed that LT is regarded as a particular program during the discussion due to its speed in providing translation results. However, it was their first time using this tool to practice translation. It indicated that they were unaware of it before.

On the other hand, the students expressed reservations about LT's ability to prepare them for a career as a professional translation. During the interview, they felt that with enough practice, they could become a professional translator, but the others were unsure since they believed that becoming a professional translation was a lengthy process. The proportion reached was precisely 47 percent, less than 50 percent.

Figure 1

Students' perceptions about MALL

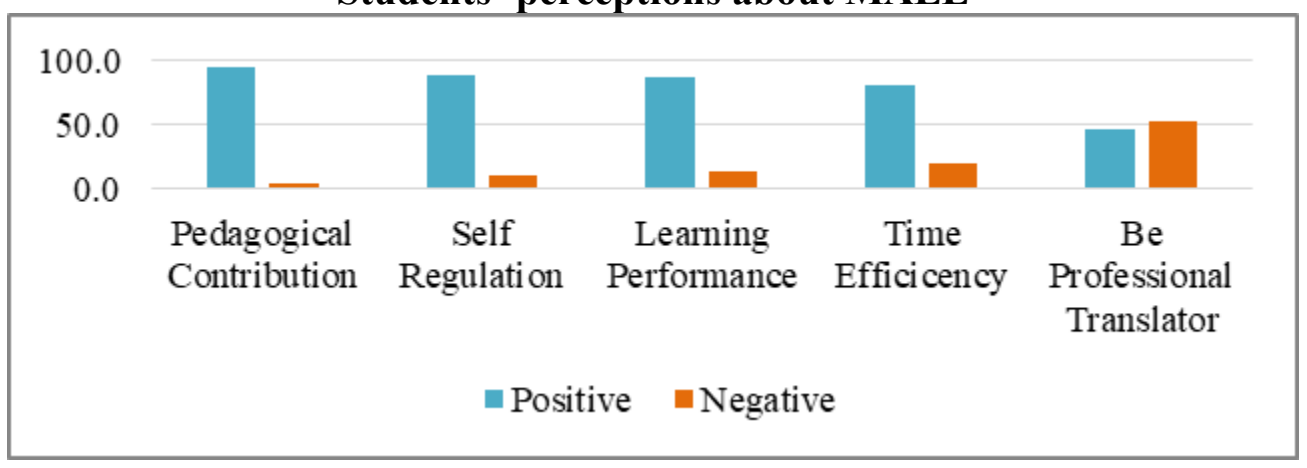

Assistance from MALL in assessing students' language ability to translate a text from English to Indonesian

MALL supported students in assessing their linguistic ability while translating a document from English to Indonesian by categorizing it into three categories: fundamental phrase, word choice, and word order, as seen in Figure 5. Simple phrases were selected by $18 \%$ of students, whereas word options were selected by $37 \%$ of 
students. The majority of students, 45 percent in total, said that MALL benefited them in identifying the word order in a text translation.

Figure 2

Mall Assistance of Students' Linguistic Competence

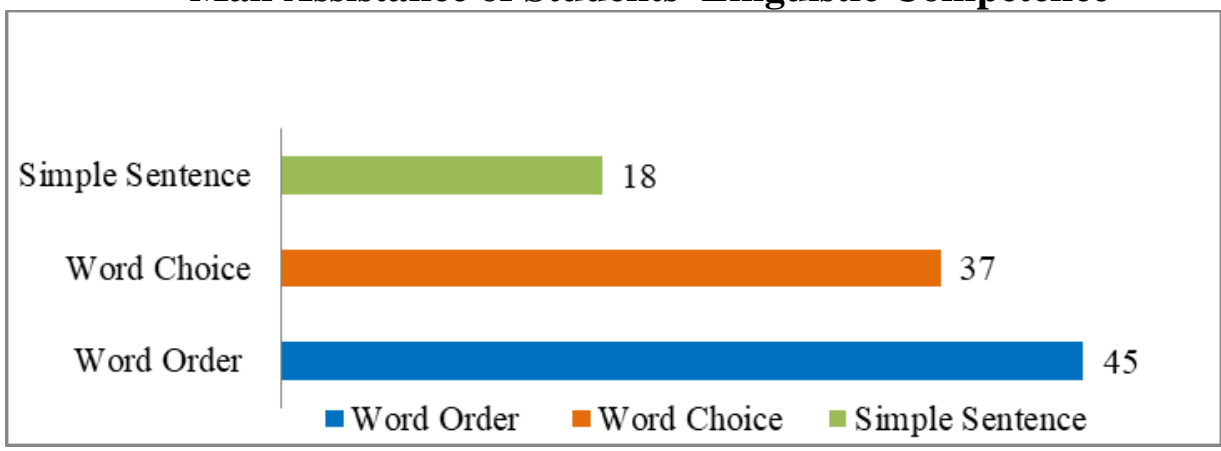

The document analysis discovered that the students accepted five basic phrases, five-word ordering, and five-word selections from the LT as the translation result while dealing with the text's subject, i.e., Coronavirus. This explained the students' reliance on LT for translation, as seen in the examples below.

Table 4 Simple Sentences

\begin{tabular}{|c|c|}
\hline Source Text (ST) & Target Text (TT) \\
\hline $\begin{array}{l}\text { 1. New variants of concern have } \\
\text { changed the game. }\end{array}$ & $\begin{array}{l}\text { Varian baru yang menjadi perhatian telah } \\
\text { mengubah permainan. }\end{array}$ \\
\hline $\begin{array}{l}\text { 2. We need to accelerate the vaccine } \\
\text { program in all countries. }\end{array}$ & $\begin{array}{l}\text { Kita perlu mempercepat program vaksin di } \\
\text { semua negara. }\end{array}$ \\
\hline 3. No one is truly safe from Covid-19. & $\begin{array}{l}\text { Tidak ada yang benar-benar aman dari Covid- } \\
19\end{array}$ \\
\hline 4. We call for urgent action. & kami menyerukan tindakan segera. \\
\hline $\begin{array}{l}\text { 5. Global rollout of vaccines is no } \\
\text { longer a guarantee of victory over } \\
\text { Covid-19. }\end{array}$ & $\begin{array}{l}\text { Peluncuran vaksin secara Global bukan lagi } \\
\text { jaminan kemenangan atas Covid-19 }\end{array}$ \\
\hline
\end{tabular}

Table 5

Word Choice

\begin{tabular}{rll}
\hline No & \multicolumn{1}{c}{ Source Text (ST) } & \multicolumn{1}{c}{ Target Text (TT) } \\
\hline 1. & in a race & berpacu \\
\hline 2. & rollout & peluncuran \\
\hline 3. & immunity & kekebalan \\
\hline 4. & taskforce & gugus tugas \\
\hline 5. & genomic surveillance & pengawasan genomik \\
\hline
\end{tabular}

Table 6

Word Order

\begin{tabular}{rll}
\hline No & \multicolumn{1}{c}{ Source Text (ST) } & \multicolumn{1}{c}{ Target Text (TT) } \\
\hline 1. & global transmission rates & tingkat transmisi global \\
\hline 2. & strong public health measures & $\begin{array}{l}\text { langkah-langkah kesehatan masyarakat yang } \\
\text { kuat }\end{array}$ \\
\hline 3. & in an equitable way & secara adil \\
\hline
\end{tabular}


4. a successful global rollout of current peluncuran vaksin global yang sukses vaccines

5. current pandemic control efforts upaya pengendalian pandemi saat ini

The following result is related to Baleghizadeh \& Oladrostam (2010) research. The researchers tried to identify if MALL might be used to help EFL students improve their grammatical skills. The experimental group utilized their phones to record their voices during class talks designed to elicit the needed grammatical elements. Then, they assessed and commented on their spoken errors during an out-of-class exercise the following session. According to the findings, individuals who got mobile-assisted learning performed much better than those in the control group on a multiple-choice grammar posttest. Gharehblagh (2020) concurs with this conclusion. Individuals in both groups significantly improved on posttests of immediate and delayed writing; however, the experimental MALL group outperformed the control group on average. As expected, the therapy group produced fewer errors with the targeted grammatical structures.

\section{Students' issues with MALL-based English-to-Indonesian translation}

The students encountered two sorts of challenges when using MALL to translate the material from English to Indonesia, as indicated in Figure 6: technical issues and guide availability. According to $53 \%$ of students, technical concerns are more challenging than guide availability. The remaining students (47 percent) said they need guidance to utilize the LT as a MALL.

According to the interview results, they had technical issues such as 1) not being able to access their translation history. 2) It took a long time to load when utilized online. 3) At the time of download, Internet data and a comparable program had the same name. Furthermore, several students said they still wanted assistance for the first time they used LT since it was their first time. Some of them, though, made contradicting statements. They had a great understanding of how to utilize LT since they had participated in an online session led by researchers. 


\section{Figure 3}

The Students' Difficulties

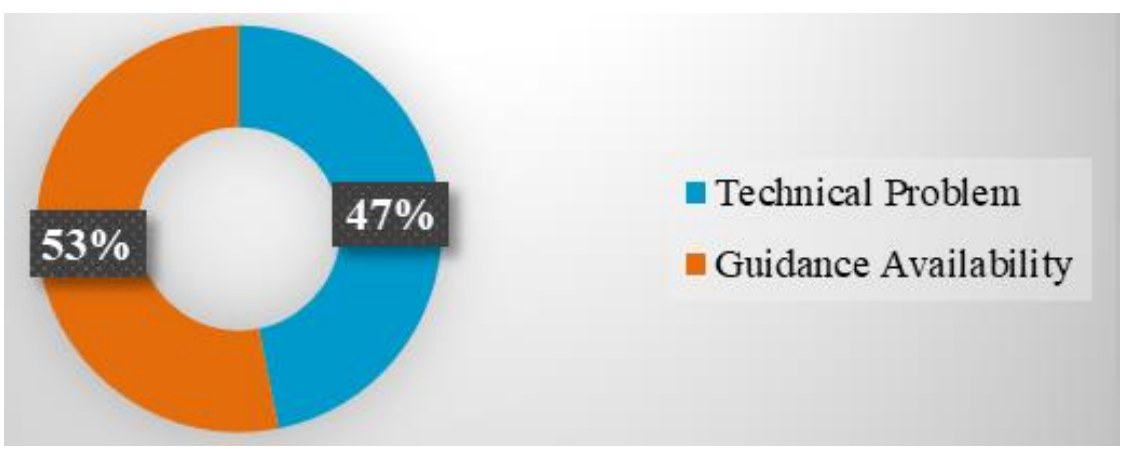

\section{Discussion}

Mobile technology has been helpful in language acquisition because of the MALL's inherent characteristics of mobility, social interaction, context sensitivity, connectivity, distinctiveness, and immediacy. This is supported by interview data, which reveal that respondents had a favorable impression of the MALL. Students are asked eight questions, and the following are the most often given responses to each. To fully exploit the advantages of mobile devices for English language learning and teaching, the study proposes that their influence on English language competence be investigated. According to previous research/studies, MALL has emerged as a potentially effective aid in the complex process of language acquisition (Taj et al., 2016). The purpose of this meta-analysis was to summarize what has been discovered so far about MALL. The findings indicate that the MALL platform is useful for EFL instruction AbuSa'aleek (2014).

However, a technological issue, such as the lack of availability of the Google Translation (GT) speaker setting option, became one of the issues that the students had to deal with about the MALL. When students hear the native speaker voice of GT sputtering, it makes it difficult for them to use it. Moreover, refer to Brindley (1998), the biggest challenge in hearing is the listener's inability to regulate the speaker's pace. This was in line with (Herlina et al., 2019; Rahmannia \& Triyono, 2019) studies. The result of the study revealed that GT may be useful to help translate few words, phrase, and particular sentence in general, and also gives a general comprehension in translating text. However, it may not give an adequate result as a fine translation product. 


\section{CONCLUSION}

The results and discussion indicate that using LT as MALL has a beneficial effect on students' capacity to translate a text from English to Indonesian. This is shown by the pupils' ability to translate material on coronaviruses from English to Indonesian. The paired samples T-test revealed a significant difference between pretest and posttest $(\mathrm{t}$ $(46)=12.8$ and p.001), with a moderate effect size $($ Cohens $d=1.89)$ indicating that the students' translation abilities may have improved as a result of utilizing MALL. An online poll and semi-structured interviews have also yielded encouraging results for the students. They feel that MALL aids them in translating material because of its speed, simplicity of use, and ability to translate up to one paragraph. MALL also teaches children how to put words in the right sequence and compose sentences. However, they determined that MALL could not vouch for them as a competent translator due to the lengthy procedure. This research suggests employing another text type of source language, such as from literary works to be translated through MALL by students. They will experience another function of MALL. Therefore, the comparison of the students' difficulty in translating the literary text and reporting text might be considered.

\section{REFERENCES}

Abbuhl, R. (2015). Experimental research methods in language learning. Modern Language Journal, 99(3).

AbuSa'aleek, A. O. (2014). A review of emerging technologies: Mobile Assisted Language Learning (MALL). Asian Journal of Education and E-Learning, 2(6), Article 6. https://ajouronline.com/index.php/AJEEL/article/view/1995

Alona, F. B., \& Hagit, M. T. (2019). Mobile technologies in educational organizations. IGI Global.

Amalia, I. (2020). The application of Mobile Assisted Language Learning (MALL) in teaching pronunciation. IJLECR - International Journal of Language Education and Culture Review, 6(2), 194-203. https://doi.org/10.21009/IJLECR.062.20

Brindley, G. (1998). Assessing listening abilities. Annual Review of Applied Linguistics, 18. https://doi.org/10.1017/s0267190500003536

Bryman, A. (2015). Social research methods (4th Edition) by Alan Bryman. Abhigyan $V O-32,4$.

Baleghizadeh, S., \& Oladrostam, E. (2010). The effect of Mobile Assisted Language Learning (MALL) on grammatical accuracy of EFL students. 34(2). https://www.mextesol.net/journal/index.php?page=journal\&id_article=50

Creswell, J. W. (2014). Research design: Qualitative, quatitative and mixed method approaches. Fourth Edition. In Singapore University of Nebraska-Lincoln.

Darsih, E., \& Asikin, N. A. (2020). Mobile assisted language learning: EFL learners' perceptions toward the use of mobile applications in learning English. English 
Review: Journal of English Education, 8(2), 183-194. https://doi.org/10.25134/erjee.v8i2.2999

Ekinci, C. E., \& Ekinci, N. (2017). A study on the relationships between teachers' critical thinking dispositions and their perceptions of occupational professionalism. Educational Process: International Journal. http://edupij.com/index/arsiv/21/98/a-study-on-the-relationships-betweenteachers-critical-thinking-dispositions-and-their-perceptions-of-occupationalprofessionalism

Fansury, A. H., Rahman, M. A., \& Jabu, B. (2021). Developing mobile English application as teaching media: Pengembangan aplikasi bahasa Inggris sebagai media pembelajaran. Deepublish.

Fitria, T. N. (2021a). Analysis on clarity and correctness of google translate in translating an Indonesian article into English. International Journal of Humanity Studies (IJHS), 4(2), 256-266. https://doi.org/10.24071/ijhs.v4i2.3227

Fitria, T. N. (2021b). A review of machine translation tools: The translation's ability. Language Circle: Journal of Language and Literature, 16(1), 162-176. https://doi.org/10.15294/lc.v16i1.30961

Gharehblagh, N. M. (2020). Developing EFL elementary learners' writing skills through Mobile-Assisted Language Learning (MALL). Teaching English with Technology, 20(1), 18.

Habibie, A. (2021). Exploring the use of mobile assisted language learning in university students context. Scope: Journal of English Language Teaching, 5(2). https://doi.org/10.30998/scope.v5i2.8537

Herlina, N., Dewanti, R., \& Lustiyantie, N. (2019). Google translate as an alternative tool for assisting students in doing translation: A case study at Universitas Negeri Jakarta, Indonesia. BAHTERA : Jurnal Pendidikan Bahasa Dan Sastra, 18(1). https://doi.org/10.21009/bahtera.181.06

Islam, A. B. M. S., \& Hasan, M. (2020). The effectiveness of Mobile Assisted Language Learning (MALL) on ESL listening skill. NOBEL: Journal of Literature and Language Teaching, 11(2), 188-202. https://doi.org/10.15642/NOBEL.2020.11.2.188-202

Nababan, R. (2003). Teori menerjemah bahasa Inggris. Pustaka Pelajar. https://www.goodreads.com/book/show/2160823.Teori_Menerjemah_Bahasa_In ggris

Orkun, Y. (2020). Recent developments in individual and organizational adoption of ICTs. IGI Global.

Rahmannia, (Mia, \& Triyono, (Sulis. (2019). A study of google translate translations: an error analysis of Indonesian-to-English texts. International Journal of Linguistics, Literature and Translation, 2(3). https://doi.org/10.32996/ijllt.2019.2.3.22

Roever, C., \& Phakiti, A. (2017). Quantitative methods for second language research. In Quantitative methods for Second Language Research. https://doi.org/10.4324/9780203067659

Rukminingsih, Adnan, G., \& Latief, M. A. (2020). Metode penelitian pendidikan. penelitian kuantitatif, penelitian kualitatif, penelitian tindakan kelas. In Journal of Chemical Information and Modeling (Vol. 53, Issue 9).

Sanz, A. M. G., Levy, M., Blin, F., \& Barr, D. (2015). World CALL: Sustainability and computer-assisted language learning. Bloomsbury Publishing. 
Taj, I. H., Sulan, N. B., Sipra, M. A., \& Ahmad, W. (2016). Impact of Mobile Assisted Language Learning (MALL) on EFL: A meta-analysis. Advances in Language and Literary Studies, 7(2), 76-83.

Wu, T.-T., Huang, Y.-M., Shadiev, R., Lin, L., \& Starčič, A. I. (2018). Innovative technologies and learning: first international conference, ICITL 2018, Portoroz, Slovenia, August 27-30, 2018, Proceedings. Springer.

Yang, J. (2013). Mobile assisted language learning: Review of the recent applications of emerging mobile technologies. English Language Teaching, 6(7), p19. https://doi.org/10.5539/elt.v6n7p19 